\title{
DAMPAK ALOKASI DANA DESA TERHADAP PEMBANGUNAN DAN KESEJAHTERAAN MASYARAKAT DESA DI KABUPATEN BANTUL DAERAH ISTIMEWA YOGYAKARTA
}

\author{
Siti Muslihah", Hilda Octavana Siregar*, Sriniyati ${ }^{\#}$ \\ *Universitas Gadjah Mada \\ Departemen Ekonomika dan Bisnis Sekolah Vokasi \\ Jl. Prof.Dr.Mr.Drs. Notonegoro, Bulaksumur, Yogyakarta \\ E-mail: siti.muslihah@ugm.ac.id \\ E-mail: hilda.octavana.s@mail.ugm.ac.id \\ \#Akademi Akuntansi YKPN \\ Jl. Gagak Rimang, Gondokusuman, Yogyakarta \\ E-mail: rsriniyati@gmail.com
}

\begin{abstract}
Abstrak
Penelitian ini bertujuan untuk mengetahui dampak Dana desa terhadap pembangunan dan kesejahteraan di wilayah Kabupaten Bantul Daerah Istimewa Yogyakarta. Penelitian dilakukan dengan membandingkan indikator pembangunan dan kesejahteraan antara sebelum dan setelah adanya Dana desa. Penelitian ini menggunakan sampel sebanyak 75 desa yang ada di Kabupaten Bantul. Metoda analisis data menggunakan uji beda dua rata-rata untuk melihat dampak yang dihasilkan dari alokasi Dana desa. Hasil pengujian menunjukkan bahwa terdapat perbedaan yang signifikan pada pembangunan fisik dan kesejahteraan masyarakat antara sebelum adanya Dana desa dan setelah diberikannya Dana desa. Hasil tersebut menunjukkan bahwa pemberian Dana desa oleh pemerintah memberikan dampak terhadap pembangunan fisik dan kesejahteraan masyarakat di Kabupaten Bantul Daerah Istimewa Yogyakarta.
\end{abstract}

Kata kunci: Dana desa, Pembangunan, kesejahteraan, uji beda dua rata-rata

\begin{abstract}
This study aimed to determine the impact of village funds on development and welfare in Bantul Regency Special Region of Yogyakarta. The study was conducted by comparing indicators of development and welfare between before and after the village funds. The sample of the study was 75 villages of Bantul Regency. The data analysis used paired sample t-test to saw the impact resulting from the allocation of village funds. The test results showed that there were significant differences in physical development and community welfare between before the existence of village funds and after the village funds were given. These results indicated that the provision of village funds by the government has an impact on physical development and community welfare in the Bantul Regency Special Region of Yogyakarta.
\end{abstract}

Keywords: village funds, development, welfare, paired sample t-test 


\section{Pendahuluan}

Berdasarkan Undang-Undang Nomor 6 Tahun 2014 Tentang Desa, desa adalah desa dan desa adat atau yang disebut dengan nama lain, selanjutnya disebut desa, adalah kesatuan masyarakat hukum yang memiliki batas wilayah yang berwenang untuk mengatur dan mengurus urusan pemerintahan, kepentingan masyarakat setempat berdasarkan prakarsa masyarakat, hak asal usul, dan/atau hak tradisional yang diakui dan dihormati dalam sistem pemerintahan Negara Kesatuan Republik Indonesia. Pemerintah Desa adalah Kepala Desa atau yang disebut dengan nama lain dibantu perangkat Desa sebagai unsur penyelenggara Pemerintahan Desa.

Sebagai bentuk dukungan atas pelaksanaan tugas dan fungsi desa dalam penyelenggaraan pemerintahan dan pembangunan desa dalam segala aspeknya sesuai dengan kewenangan yang dimiliki, UU Nomor 6 Tahun 2014 memberikan wewenang kepada Pemerintah untuk mengalokasikan Dana Desa. Dana Desa tersebut dianggarkan setiap tahun dalam APBN yang diberikan kepada setiap desa sebagai salah satu sumber pendapatan desa. Kebijakan ini sekaligus mengintegrasikan dan mengoptimalkan seluruh skema pengalokasian anggaran dari Pemerintah kepada desa yang selama ini sudah ada. Sumber-sumber pendapatan Desa yaitu; (1) pendapatan asli desa (2) Dana desa yang bersumber dari APBN (3) bagian dari hasil PDRD Kab/kota (4) alokasi Dana desa dari Kab/Kota (5) bantuan keuangan dari APBD Provinsi dan APBD Kab/Kota (6) hibah dan sumbangan pihak ketiga dan (7) lain-lain pendapatan desa yang sah. Tujuan diberikannya Dana desa adalah untuk meningkatkan pelayanan publik di desa, mengentaskan kemiskinan, memajukan perekonomian desa, mengatasi kesenjangan pembangunan antardesa serta memperkuat masyarakat desa sebagai subjek dari pembangunan.

Evaluasi merupakan salah satu hal yang penting dalam pengelolaan Dana desa. Evaluasi diperlukan untuk memastikan agar pada setiap tahapan pengelolaan Dana desa tidak terjadi penyimpangan. Secara umum, proses evaluasi dilakukan sejak dari tahap perencanaan sampai dengan laporan pertanggungjawaban. Pelaksanaan evaluasi dilakukan secara berjenjang dari level pusat hingga daerah. Proses evaluasi di tingkat pusat dilakukan oleh Kementerian Keuangan, bersama dengan Kementerian Dalam Negeri dan Kementerian Desa dan PDTT. Proses pelaksanaan evaluasi oleh pemerintah pusat dilakukan secara sinergis dan terpadu. Hal tersebut sangat diperlukan untuk memastikan bahwa penggunaan Dana desa sesuai dengan prioritas yang ditetapkan dan untuk memastikan bahwa ketercapaian output dapat lebih maksimal. Pemerintah juga telah menetapkan 86 | Jurnal Akuntansi, Ekonomi dan Manajemen Bisnis|Vol. 7 No.1, July 2019, 85-93|E-ISSN: 2548-9836 mekanisme pemberian sanksi apabila terdapat penyimpangan dalam implementasi pengelolaan Dana desa.

Adanya Dana desa diharapkan dapat memberikan dampak yang signifikan bagi masyarakat, baik terhadap pembangunan maupun kesejahteraan. Untuk mencapai hal tersebut, masyarakat harus ikut berpartisipasi dalam penyusunan program-program yang akan diDanai oleh alokasi Dana desa. Hal ini diharapkan dapat mewujudkan Rencana Pembangunan Jangka Menengah Nasional (RPJMN) 2015-2019, visi, misi, dan agenda (nawa cita) yang berfungsi untuk menjadi menjadi pedoman kementerian/lembaga dalam menyusun rencana strategis dan acuan dasar dalam pemantauan dan evaluasi RPJMN. RPJMN juga dapat menjadi acuan bagi masyarakat yang berpartisipasi dalam pelaksanaan pembangunan normal.

Beberapa pemaparan tersebut menunjukkan bahwa evaluasi dan pengawasan terhadap Dana desa merupakan hal yang penting. Dana desa merupakan hal yang diharapkan dapat membawa perubahan yang cepat bagi masyarakat desa. Penelitian ini kemudian diharapkan dapat memberikan gambaran bagaimana dampak alokasi alokasi Dana desa terhadap pembangunan fisik serta kesejahteraan masyarakat. Pembangunan fisik dalam hal ini adalah pembangunan infrastruktur serta sarana yang menunjang kehidupan masyarakat desa. Kesejahteraan masyarakat pada paper ini merupakan tingkat kemiskinan.

\section{Tinjauan Pustaka}

Dalam rangka mendukung pelaksanaan tugas dan fungsi desa dalam penyelenggaraan pemerintahan dan pembangunan desa dalam segala aspeknya sesuai dengan kewenangan yang dimiliki, UU Nomor 6 Tahun 2014 memberikan mandat kepada Pemerintah untuk mengalokasikan Dana desa. Dana desa tersebut dianggarkan setiap tahun dalam APBN yang diberikan kepada setiap desa sebagai salah satu sumber pendapatan desa. Kebijakan ini sekaligus mengintegrasikan dan mengoptimalkan seluruh skema pengalokasian anggaran dari Pemerintah kepada desa yang selama ini sudah ada.

\section{Berdasarkan Buku Pintar Dana Desa} (2017), saat ini masih terdapat anggaran Kementerian/Lembaga (K/L) yang berbasis desa mencapai sekitar $0,28 \%$ dari total anggaran $\mathrm{K} / \mathrm{L}$ Tahun 2017. Dana-Dana tersebut selanjutnya diintegrasikan dalam skema penDanaan Dana desa,

\section{Dana Desa}


sehingga pembangunan desa menjadi lebih optimal. Dana desa adalah Dana APBN yang diperuntukkan bagi desa yang ditransfer melalui APBD kabupaten/kota dan diprioritaskan untuk pelaksanaan pembangunan; dan pemberdayaan masyarakat desa. Dana desa dihitung berdasarkan jumlah desa dan dialokasikan dengan memperhatikan: jumlah penduduk, angka kemiskinan, luas wilayah, dan tingkat kesulitan geografis.

Menurut Fitri (2015), pengelolaan alokasi Dana desa selayaknya dapat mencerminkan komitmen pemerintah daerah untuk melaksanakan pemerintahan yang tidak mengorbankan kepentingan publik (public sphere). Selama ini, pembiayaan pembangunan desa masih bergantung pada pendapatan asli desa dan swadaya masyarakat yang jumlah maupun sifatnya tidak dapat diprediksi. Oleh karena itu, dalam rangka mendukung pembangunan di wilayah pedesaan, pemerintah pusat mengarahkan kepada beberapa kabupaten untuk melakukan pengalokasian Dana langsung ke desa dari APBD-nya. Pemerintah juga menyatakan bahwa adanya otonomi yang dimiliki oleh desa ataupun dengan sebutan lainnya dan kepala desa melalui pemerintahan desa dapat diberikan penugasan ataupun pendelegasian dari pemerintah pusat maupun daerah untuk melaksanakan urusan-urusan pemerintah tertentu. Disamping itu, setiap upaya pembangunan di kawasan perdesaan yang dilakukan oleh pemerintah kabupaten/kota dan atau pihak ketiga harus mengikutsertakan pemerintahan desa.

\section{Pembangunan Desa}

Peraturan Menteri Desa, Pembangunan Daerah Tertinggal, dan Transmigrasi Nomor 3 tahun 2015 tentang Pendampingan Desa mendefinisikan pembangunan desa sebagai upaya peningkatan kualitas hidup dan kehidupan untuk sebesarbesarnya kesejahteraan masyarakat Desa. Pembangunan desa tidak terlepas dari manajemen pembangunan daerah, baik di tingkat kabupaten maupun provinsi, karena pembangunan desa harus melihat keterkaitan antara antardesa, desa dalam kecamatan, antarkecamatan dan kabupaten, serta antarkabupaten.

Pembangunan desa memiliki peran penting dalam pembangunan nasional. Pembangunan desa tidak hanya mencakup pembangunan fisik, tapi juga pembangunan non fisik. Oleh karena itu, sumber daya manusia yang menjadi pelaksana pembangunan desa harus diperhatikan dan dikembangkan dengan baik pula.
Terdapat perdebatan yang mewarnai pemikiran tentang pembangunan pedesaan di Indonesia pada masa Orde Baru dan awal Orde Reformasi, yaitu mengenai pendekatan yang digunakan dalam pembangunan itu sendiri. Secara sederhana terdapat tiga kutub pemikiran tentang pembangunan pedesaan di Indonesia. Kelompok pertama melihat wilayah pedesaan dan masyarakatnya sebagai sesuatu yang khas dan spesifik, dan dalam menggerakan pembangunan di wilayah pedesaan, pendekatan yang digunakan adalah dengan sedikit mungkin campur tangan pemerintah. Pada sisi lain, para pemikir yang melingkari kekuasaan pada saat itu, sebagai kelompok kedua, cenderung melihat desa sebagai sesuatu yang homogen dan perlu digerakkan dengan campur tangan pemerintah yang maksimal. Pemikiran inilah yang melandasi disusunnya berbagai cetak biru pembangunan pedesaan dan ditetapkannya berbagai peraturan perundangan yang menjadikan desa sebagai suatu wilayah yang homogen dan steril dari kegiatan politik praktis, serta menjadi alat pemerintah dalam pembangunan.

Kelompok ketiga mencoba menyeimbangkan kekuatan masyarakat pedesaan dan negara dalam menentukan arah dan tujuan perubahan sosial yang terjadi dalam masyarakat pedesaan. Beberapa pemikiran dari kelompok pertama antara lain dapat diikuti pada tulisan Tjondronegoro (1978), Pincus (1996), serta Rozelle dan Swinnen (2000) yang menekankan perlunya dilakukan transformasi kekuasan politik dan penguasaan alat-alat produksi kepada lapisan masyarakat yang memiliki potensi produksi terbesar, tetapi berada dalam kedudukan yang lemah. Kelompok ini mensyaratkan perlunya dilakukan pengaturan kembali struktur penguasaan atas tanah, sistem hubungan penguasaan, pemilikan, sakap-menyakap sebagai dasar dalam modernisasi pedesaan. Kegiatan industri akan berkembang sebagai akibat surplus dari pertanian, dan kelebihan tenaga kerja dari pertanian secara bertahap akan diserap sektor pengolahan hasil pertanian dan industri. Pemikiran kelompok kedua dapat di lihat dalam tulisan Pakpahan (2000) dan Lokollo (2004), dan para teknokrat Orde Baru, yang menekankan pada upaya penyeragaman pendekatan dalam pembangunan pedesaan. Pemikiran dari kelompok inilah yang banyak mewarnai berbagai kebijakan pembangunan pedesaan di Indonesia, terutama pada masa Orde Baru.

Pemikiran kelompok ketiga antara lain dapat dilihat pada tulisan Soetrisno (1988), yang menyatakan harus ada equal-partnership antara rakyat desa dan 
aparat perencana dan pelaksana pembangunan. Beberapa persepsi yang keliru dalam pelaksanaan pembangunan pedesaan adalah persepsi bahwa aparat desa merupakan sumber energi dalam pembangunan dan bukan sumber informasi (Soetrisno, 1988). Selain itu, masyarakat desa sering kali diposisikan sebagai pihak yang digerakkan untuk mendukung pembangunan yang direncanakan dan dilaksanakan pemerintah tanpa diminta pendapatnya. Soetrisno (1988) juga menyatakan bahwa sistem panutan dalam pembangunan pedesaan sebagai sesuatu yang tidak berdasar, dan desa di Indonesia beragam sehingga hendaknya tidak ada upaya penyeragaman. Sistem cetak biru dalam pembangunan pedesaan akan membuat pembangunan efisien, namun tidak menumbuhkan partisipasi dari masyarakat. Tidak ada yang keliru dari ketiga pendekatan tersebut karena semuanya mempunyai dasar berpijak dan alasan yang kuat. Namun, ketiga pemikiran tersebut belum dengan jernih memilah persoalan masyarakat desa sebagai persoalan individu masyarakat dan sebagai persoalan suatu komunitas. Bila hal ini dapat dipilah dengan baik maka pentahapan pembangunan pedesaan dapat dilakukan dengan melihat tingkat perkembangan kebutuhan mereka secara individu dan sebagai sebuah komunitas.

Pemerintah berusaha untuk keluar dari berbagai masalah ketimpangan pembangunan antara desa dengan kabupaten/kota melalui alokasi Dana desa. Alokasi Dana desa diharapkan dapat menghasilkan berbagai output sarana dan prasarana publik desa, serta dampak yang baik terhadap kualitas hidup masyarakat desa. Adanya alokasi Dana desa diharapkan dapat menjadikan desa memiliki sarana dan fasilitas yang memadai sehingga dapat menunjang kehidupan masyarakat sehari-hari.

\section{Kesejahteraan Masyarakat Desa}

Menurut Sulistiyani (2004), pemberdayaan merupakan suatu proses menuju budaya, atau proses untuk memperoleh daya atau kekuatan atau kemampuan, dan atau proses pemberian daya kepada pihak yang kurang atau belum berdaya. Pemberdayaan menekankan bahwa orang memperoleh keterampilan, pengetahuan dan kekuasaan yang cukup untuk mempengaruhi kehidupannya dan kehidupan orang lain yang menjadi perhatiannya.

Kesejahteraan menurut Poerwadarminta (2000) adalah aman, sentosa, dan makmur. Arti kesejahteraan meliputi keamanan, keselamatan, dan kemakmuran. Kesejahteraan atau biasa disebut kesejahteraan sosial merupakan serangkaian aktifitas yang terorganisasi yang ditunjukan untuk meningkatkan kualitas hidup, relasi sosial, serta peningkatan kehidupan masyarakat yang selaras dengan standar dan norma-norma masyarakat sebagai tujuan, cita-cita, pedoman dan aspirasi agar terpenuhi kebutuhan materi, sosial dan spiritual.

Berdasarkan Undang-Undang No. 11 Tahun 2009 Tentang Kesejahteraan Sosial, kesejahteraan masyarakat ialah kondisi terpenuhinya kebutuhan material, spiritual, dan sosial warga negara agar dapat hidup layak dan mampu mengembangkan diri, sehingga dapat melaksanakan fungsi sosialnya. Ukuran tingkat kesejahteraan dapat diukur dengan kemampuan seseorang dalam memenuhi kebutuhan material dan spiritualnya.

Dalam peningkatan kesejahteraan masyarakat desa pemerintah desa salah satu di dukung oleh adanya pengelolaan badan usaha milik desa atau Bumdes. Pembentukan Bumdes di masukan guna mendorong dan menampung seluruh kegiatan peningkatan pendapatan masyarakat, baik yang berkembang menurut adat istiadat/ budaya setempat, maupun kegiatan perekonomian yang di serahkan untuk dikelola oleh masyarakat melalui program/proyek pemerintah dan pemerintah daerah. Pemberian Dana desa diharapkan dapat mendukung masyarakat dalam mengembangkan desa dan meningkatkan kesejahteraan.

\section{Penelitian Terdahulu}

Beberapa penelitian terkait dengan Dana desa, pembangunan, dan kesejahteraan masyarakat telah dilakukan di Indonesia. Mahfudz (2009) melakukan penelitian mengenai dampak alokasi Dana desa terhadap pemberdayaan masyarakat dan kelembagaan desa. Pada aspek pengalokasian ADD, sebagian besar penggunaan ADD ternyata lebih banyak diarahkan pada kegiatan fisik (pembangunan sarana dan prasarana fisik), disusul kemudian untuk penambahan kesejahteraan perangkat desa dalam bentuk Dana purna bakti, tunjangan dan sejenisnya serta sebagian lagi untuk kegiatan rutin.

Oleh (2014) melakukan penelitian mengenai kebijakan alokasi Dana desa dalam memberdayakan masyarakat. Penelitian dilakukan di Desa Cerme, Kecamatan Grogol, Kabupaten Kediri. Adanya Dana desa yang harus dikelola secara mandiri memberikan dampak yang positif baik bagi pemerintah desa maupun masyarakat Desa Cerme. Selain itu, kehadiran ADD juga memberikan keleluasan dari Desa Cerme untuk 
mengelola pemerintah desa, pembangunan serta sosial kemasyarakatannya secara otonom. Pelaksanaan ADD yang didalamnya terdapat proses perencanaan, pelaksanaan dan evaluasi sesuai dengan tahapan-tahapan yang ada dalam pemberdayaan masyarakat. Keterlibatan masyarakat dalam pelaksanaan ADD mengkondisikan masyarakat berada pada tahapan pemberdayaan, dimana semua itu mengarah pada masyarakat yang mandiri pada akhirnya.

Saputra (2016) meneliti tentang efektifitas pengelolaan Dana desa pada Desa Lembean di Kabupaten Bangli. Hasil penelitian menunjukkan bahwa efektivitas pengelolaan alokasi Dana desa dari tahun 2009-2014 sudah berada dalam kategori efektif. Tingkat efektivitas pengelolaan alokasi Dana desa pada Desa Lembean yaitu tahun 2009 (98,98\%), 2010 (100\%), 2011 (100\%), 2012 (98,24\%), 2013 (100\%), dan 2014 (99,57\%). Meski demikian, Desa Lembean masih mengalami kesulitan dalam merealisasikan alokasi Dana desa. Hambatan tersebut kemudian diatasi dengan melakukan pelatihan, meningkatkan kordinasi unit kerja, dan anggaran Dana cadangan.

Daraba (2017) melakukan penelitian mengenai pengaruh Dana desa terhadap pastisipasi masyarakat di Kecamatan Galesong Utara. Hasil penelitian menunjukkan adanya pengaruh positif signifikan Dana desa terhadap tingkat partisipasi masyarakat. Program Dana desa mempunyai konstribusi sebesar 0,329 terhadap peningkatan partisipasi masyarakat. Nilai R2 terkoreksi sebesar 0,789. Nilai ini menjelaskan bahwa sebanyak 78,9 $\%$ variasi yang berbeda dari tingkat partisipasi masyarakat ditentukan oleh program Dana desa pada taraf signifkansi $=0,05$.

Nafidah dan Anisa (2017) meneliti tentang akuntabilitas pengelolaan keuangan desa di Kabupaten Jombang. Hasil penelitian menunjukkan bahwa pengelolaan keuangan desa di beberapa desa di Kabupaten Jombang telah dikelola dengan akuntabel, mulai dari tahap perencanaan sampai tahap pertanggungjawaban. Beberapa kendala yang dihadapi oleh desa di Kabupaten Jombang diantaranya adalah kelambatan pencairan anggaran, kemampuan sumber daya manusia yang terbatas, dan kurang maksimalnya pendampingan desa. Sari dan Abdullah (2017) menganalisis ekonomi kebijakan Dana desa terhadap kemiskinan di Temanggung. Hasil analisis menunjukkan bahwa adanya Dana desa berpengaruh terhadap kemiskinan yang ada di Temanggung.

\section{Pengembangan Hipotesis}

Pembangunan fisik dapat didefinisikan sebagai pembangunan yang dapat dirasakan langsung oleh masyarakat atau pembangunan yang tampak oleh mata (Kuncoro, 2010, p.20). Perubahan identik dengan adanya wujud atau bentuk dari pembangunan, misalnya sarana perumahan, sarana peribadahan, sarana pembuatan jalan, sarana pendidikan, dan sarana umum lainnya. Pembangunan fisik contohnya adalah dengan membangun jalan, jembatan, lapangan terbang, gedung, pelabuhan, dan lain sebagainya.

Pembangunan fisik dilakukan agar masyarakat dapat menggunakan sarana infrastruktur yang ada untuk menunjang aktivitas kehidupan sehari-hari. Mahfudz (2009) menyatakan bahwa sebagian besar penggunaan ADD lebih banyak diarahkan pada kegiatan fisik (pembangunan sarana dan prasarana fisik). Adanya alokasi Dana desa pembangunan fisik di desa bisa dilakukan sesuai kebutuhan masyarakat. Pembangunan yang disesuaikan dengan kebutuhan desa masing-masing dapat membantu masyarakat dalam memperoleh akses dan fasilitas yang memadai dan benar-benar dibutuhkan di desa tersebut.

Penelitian yang dilakukan oleh Alam, Ulwiya, dan Nurhidayah (2018) menunjukkan bahwa adanya alokasi Dana desa berkontribusi dalam pembangunan fisik di Desa Tuntang. Pembangunan yang dilakukan pada Desa Tuntang pada tahun 2018 digunakan untuk membangun talud, saluran irigasi, dan pengaspalan jalan.

H1: Terdapat perbedaan pembangunan fisik setelah adanya alokasi Dana desa

Undang-Undang No. 11 Tahun 2009 Tentang Kesejahteraan Sosial mendefinisikan kesejahteraan masyarakat sebagai kondisi terpenuhinya kebutuhan material, spiritual, dan sosial warga negara agar dapat hidup layak dan mampu mengembangkan diri, sehingga dapat melaksanakan fungsi sosialnya. Alokasi Dana Desa mendorong peningkatan taraf hidup dan kesejahteraan masyarakat desa apabila diaktifkan secara intensif dan efektif. Kesejahteraan masyarakat dapat diukur dengan kemampuannya dalam memenuhi kebutuhan material dan spiritual.

Pembangunan pedesaan sebagai sasaran pembangunan, ditujukan untuk mengurangi berbagai kesenjangan desa dan kota dan peningkatan perekonomian di Desa. Pemberian Dana Desa merupakan wujud dari pemenuhan hak desa untuk menyelenggarakan otonominya agar 
tumbuh dan berkembang. Peran pemerintah desa ditingkatkan dalam memberikan pelayanan dan kesejahteraan masyarakat serta mempercepat pembangunan dan pertumbuhan ekonomi dan wilayah yang ditujukan untuk meningkatkan kesejahteraan masyarakat desa.

Sari dan Abdullah (2017) menemukan bahwa adanya Dana desa berpengaruh terhadap kesejahteraan masyarakat, yang ditandai dengan adanya penurunan kemiskinan yang ada di Temanggung. Mahfudz (2009) menyatakan bahwa penggunaan ADD pada peringkat kedua banyak dialokasikan untuk peningkatan kesejahteraan masyarakat desa. Penelitian tersebut sejalan dengan penelitian Oleh (2014) yang menyatakan bahwa kehadiran ADD juga memberikan keleluasan pada desa untuk mengelola pemerintah desa, pembangunan, serta kesejahteraan sosial masyarakat secara otonom.

H2: Terdapat perbedaan kesejahteraan masyarakat setelah adanya alokasi Dana desa.

\section{Metode Penelitian}

Penelitian ini merupakan penelitian metode kuantitatif dengan uji beda rata-rata yaitu Paired Sample T-Test. Penelitian dilakukan dengan mengumpulkan data-data ke desa di Kabupaten Bantul Daerah Istimewa Yogyakarta. Data-data yang dikumpulkan merupakan indikator pembangunan fisik dan kesejahteraan masyarakat. Terdapat 75 (tujuh puluh lima) desa yang di Kabupaten Bantul yang merupakan populasi. Seluruh anggota populasi menjadi subjek dalam penelitian ini.

Pengumpulan data dilakukan dengan metode dokumentasi (archival data) yang berasal dari Laporan Keuangan Desa dan program-program kerja yang terkait dengan pembangunan fisik dan kesejahteraan masyarakat desa yang diDanai dengan alokasi Dana desa. Analisis dilakukan mulai dengan menghitung masing-masing indikator dari pembangunan fisik dan kesejahteraan masyarakat. Setelah pengukuran masing-masing variabel dilakukan, selanjutnya dilakukan pengujian hipotesis. Perbandingan pembangunan fisik dan kesejahteraan masyarakat sebelum dan setelah alokasi Dana desa dilakukan secara serentak.

\section{Hasil dan Pembahasan}

Analisis statistik deskriptif dilakukan untuk mengetahui nilai minimum, maksimum, rata-rata dan standar deviasi dari data pembangunan fisik dan kesejahteraan masyarakat. Data yang disajikan merupakan data pembangunan fisik dan kesejahteraan masyarakat, baik sebelum diberikannya Dana desa maupun setelah diberikannya Dana desa.

TABEL 1.

STATISTIK DESKRIPTIF

\begin{tabular}{|l|c|c|c|c|c|}
\hline & $\mathrm{N}$ & Min. & Max. & $\begin{array}{c}\text { Rata- } \\
\text { Rata }\end{array}$ & $\begin{array}{c}\text { Deviasi } \\
\text { Standar }\end{array}$ \\
\hline $\begin{array}{l}\text { Pembangunan - } \\
\text { sebelum }\end{array}$ & 75 & 0,00 & 135,00 & 47,24 & 26,42 \\
\hline $\begin{array}{l}\text { Pembangunan - } \\
\text { sesudah }\end{array}$ & 75 & 12,00 & 110,00 & 51,81 & 23,03 \\
\hline $\begin{array}{l}\text { Kesejahteraan - } \\
\text { sebelum }\end{array}$ & 75 & 0,00 & 0,77 & 0,39 & 0,15 \\
\hline $\begin{array}{l}\text { Kesejahteraan - } \\
\text { sesudah }\end{array}$ & 75 & 0,00 & 1,96 & 0,24 & 0,32 \\
\hline
\end{tabular}

Tabel 1 menunjukkan hasil analisis statistik deskriptif yang telah dilakukan. Pembangunan fisik yang dilakukan sebelum adanya pemberian Dana desa menghasilkan nilai minimum 0 , nilai maksimum 135, rata-rata 47,24, dan deviasi standar sebesar 26,42. Pembangunan fisik yang dilakukan setelah pemberian Dana desa memperoleh nilai minimum 12, maksimum 110 , rata-rata 51,81, dan deviasi standar 23,03. Kesejahteraan masyarakat pada tabel 4.1 disajikan dalam nilai desimal. Apabila dijelaskan dengan persentase, kesejahteraan masyarakat sebelum diberikannya Dana desa nilai minimumnya sebesar $0 \%$, maksimum sebesar $77 \%$, rata-rata $39 \%$ dan standar deviasi $15 \%$. Kesejahteraan masyarakat setelah diberikannya Dana desa menghasilkan nilai minimum $0 \%$, maksimum $196 \%$, rata-rata $24 \%$, dan standar deviasi $32 \%$.

Uji beda dua rata-rata dilakukan untuk menguji apakah terdapat perbedaan rata-rata antara dua sampel yang berhubungan (Ghozali, 2009, p.66). Pada penelitian ini, tujuan penelitian adalah untuk mengetahui dampak alokasi Dana desa terhadap pembangunan fisik dan kesejahteraan masyarakat. Tujuan tersebut dapat dicapai dengan melakukan uji beda dua rata-rata untuk data pembangunan fisik dan kesejahteraan masyarakat sebelum dan sesudah diberikannya Dana desa.

TABEL 2.

HASIL PENGUJIAN SAMPEL

\begin{tabular}{|l|c|c|c|}
\hline \multicolumn{1}{|c|}{ Keterangan } & $\begin{array}{c}\text { Rata- } \\
\text { Rata }\end{array}$ & $\begin{array}{c}\mathrm{t} \\
\text { hitung }\end{array}$ & $\begin{array}{c}\text { Sig. }(2 \\
\text { tailed })\end{array}$ \\
\hline Pembangunan Fisik & $-4,57$ & $-2,537$ & 0,013 \\
\hline $\begin{array}{l}\text { Kesejahteraan } \\
\text { Masyarakat }\end{array}$ & 0,15 & 3,661 & 0,000 \\
\hline
\end{tabular}

Tabel 4.2 tersebut merupakan hasil uji beda dua rata-rata untuk pembangunan fisik dan kesejahteraan masyarakat. Ghozali (2009) 90 | Jurnal Akuntansi, Ekonomi dan Manajemen Bisnis|Vol. 7 No.1, July 2019, 85-93|E-ISSN: 2548-9836 
menyebutkan bahwa perbedaan dua rata-rata signifikan secara statistik apabila nilai t hitung lebih besar dari t tabel. Besarnya signifikansi yang digunakan dalam penelitian ini adalah $95 \%$, yang memiliki nilai t tabel 1,96 .

Hipotesis pertama penelitian ini menyatakan bahwa pembangunan fisik lebih baik setelah adanya Dana desa. Pada pengujian pembangunan fisik, diperoleh t hitung sebesar -2,537 dengan tingkat signifikansi $1,3 \%$. Hasil tersebut memperoleh $\mathrm{t}$ hitung yang lebih besar dari t tabel. Hasil tersebut menunjukkan bahwa terdapat perbedaan pembangunan fisik antara sebelum adanya pemberian Dana desa dan setelah pemberian Dana desa. Artinya, hipotesis pertama penelitian ini diterima.

Oleh (2014) menyatakan bahwa pemberian Dana desa akan menghemat biaya pembangunan desa dan desa dapat mengelola sendiri proyek pembangunannya. Pembangunan yang dilakukan di desa tidak lagi hanya dibiayai oleh swadaya masyarakat. Dana desa dapat digunakan untuk membangun dan memperbaiki sarana dan fasilitas yang dimiliki oleh desa. Adanya fasilitas dan sarana yang memadai akan memudahkan akses masyarakat. Masyarakat juga akan dapat terlayani dengan baik, karena desa diberikan kewenangan untuk mengelola pembangunan dan pemerintahnnya sendiri.

Dana desa yang diperoleh oleh Kabupaten Bantul meningkat pada tahun 2018 (Sidik, 2018). Dana desa di Kabupaten Bantul dipriroritaskan untuk pembangunan dan peningkatan kesejahteraan masyarakat. Dana desa yang diperoleh digunakan untuk membangun infrastruktur, baik untuk kegiatan masyarakat maupun untuk infrastruktur pariwisata. Pembangunan infrastruktur ini juga dibarengi dengan program padat karya sehingga dapat memberdayakan masyarakat di sekitar daerah wisata.

Hipotesis kedua penelitian ini menyatakan bahwa kesejahteraan masyarakat lebih baik setelah adanya Dana desa. Pengujian kesejahteraan masyarakat menunjukkan $\mathrm{t}$ hitung 3,661 yang melebihi $\mathrm{t}$ tabel 1,96 dengan tingkat signifikansi 0\%. Hasil tersebut menunjukkan bahwa terdapat perbedaan kesejahteraan masyarakat antara sebelum adanya pemberian Dana desa dan setelah pemberian Dana desa. Dengan kata lain, hipotesis kedua penelitian ini diterima.

Hasil penelitian ini mendukung penelitian yang dilakukan oleh Sari dan Abdullah (2017) serta penelitian Tangkumahat, Panelewen, dan Mirah (2017). Mereka menemukan bahwa alokasi Dana desa berpengaruh signifikan terhadap tingkat kemiskinan di desa. Adanya Dana desa dapat membantu penyediaan fasilitas dan sarana bagi masyarakat pedesaan sehingga memenuhi kebutuhan sehari-hari dengan lebih baik. Masyarakat yang sejahtera adalah masyarakat yang standar kehidupannya sesuai dengan norma-norma, serta masyarakat yang dapat memenuhi kebutuhan materi, sosial, dan spiritualnya.

Dana desa yang diberikan oleh Pemerintah merupakan suatu usaha yang dilakukan untuk mengurangi ketimpangan yang terjadi antara desa dan kota. Adanya Dana tersebut memberikan kesempatan kepada desa untuk dapat melengkapi sarana dan prasarana yang belum dimiliki oleh desa. Dana desa juga digunakan untuk melakukan program pemberdayaan masyarakat desa sehingga masyarakat menjadi lebih mandiri (Oleh, 2014). Tangkumahat, Panelewen, dan Mirah (2017) menyebutkan bahwa adanya Dana desa meningkatkan penyerapan tenaga kerja masyarakat. Tenaga kerja tersebut melaksanakan berbagai kegiatan proyek yang diDanai oleh Dana desa serta menjadi kader-kader di Puskesmas.

Fokus dari Dana desa di Kabupaten Bantul adalah pembangunan dan kesejahteraan masyarakat. Pembangunan infrastruktur wisata di Kabupaten Bantul akan dapat memberikan manfaat ekonomi untuk masyarakat di sekitarnya sehingga dapat meningkatkan kesejahteraan. Selain itu, Kabupaten Bantul juga menggunakan Dana desa untuk mengembangkan koperasi dan BUMDes (Sidik, 2018). Tujuan dari pengembangan koperasi dan BUMDes adalah peningkatan kualitas hidup dan kesejahteraan masyarakat Kabupaten Bantul. Masyarakat juga diberikan program padat karya dan juga pelatihan untuk meningkatkan hasil pertanian mereka. Sektor pertanian menjadi perhatian, karena sebagian besar masyarakat memiliki mata pencaharian sebagai petani (Sidik, 2018).

Tujuan dari pemberian Dana desa adalah pemberdayaan masyarakat desa agar dapat memiliki kehidupan yang lebih baik. Di sisi lain, pelaksanaan dan penggunaan Dana desa masih harus diperbaiki dan ditingkatkan. Kurniawan (2018) menyebutkan bahwa pelaporan penggunaan Dana desa belum dapat dilakukan dengan tepat waktu. Selain itu, penggunaan Dana desa harus diawasi supaya tidak disalahgunakan. Upaya pelatihan terhadap aparatur desa terkait pengelolaan Dana desa juga perlu untuk dilakukan (Wardhana, 2018). Hal tersebut penting untuk mengawal Dana desa agar sepenuhnya digunakan untuk kepentingan masyarakat.

\section{Simpulan dan Saran}

Berdasarkan hasil analisis dan pembahasan yang telah dijelaskan pada bagian sebelumnya, maka dapat disimpulkan: 
1. Dana desa memberikan dampak terhadap pembangunan fisik.

Adanya Dana desa memberikan kesempatan bagi desa untuk melakukan pembangunan dan pemerintahannya sendiri. Kesempatan tersebut memungkinkan pembangunan sarana, fasilitas, dan infrastruktur desa menjadi lebih baik dan sesuai dengan kebutuhan masing-masing desa di Kabupaten Bantul Daerah Istimewa Yogyakarta.

2. Dana desa memberikan dampak terhadap kesejahteraan masyarakat.

Dana desa dapat digunakan oleh masyarakat untuk melakukan kegiatan pemberdayaan dalam mendorong produktivitas. Adanya kegiatan pemberdayaan tersebut dapat mendorong tergalinya potensi yang dimiliki masyarakat sehingga dapat meningkatkan kesejahteraan masyarakat di Kabupaten Bantul Daerah Istimewa Yogyakarta.

Kesimpulan dari penelitian ini menunjukkan bahwa adanya Dana desa memberikan dampak bagi pembangunan dan kesejahteraan masyarakat di Kabupaten Bantul. Akan tetapi, beberapa permasalahan terkait dengan pelaksanaan serta pelaporan Dana desa juga perlu mendapatkan perhatian khusus dari Pemerintah. Hal tersebut dilakukan agar pelaksanaan Dana desa berjalan dengan tepat sasaran serta pertanggungjawabannya dapat dilakukan dengan baik dan tepat waktu.

Penelitian ini dilakukan terbatas pada desa-desa di Kabupaten Bantul Daerah Istimewa Yogyakarta sehingga diperlukan kehati-hatian dalam melakukan generalisasi hasil penelitian. Penelitian selanjutnya hendaknya menggunakan cakupan wilayah desa yang lebih luas sehingga dapat meningkatkan kemampuan generalisasi hasil.

\section{Daftar Pustaka}

A. Alam, M.S., Ulwiya, A., dan Nurhidayah, M., 2018. Pemanfaatan Alokasi Dana Desa Terhadap Pembangunan Perdesaan (Studi Kasus di Tuntang Kecamatan Tuntang Kabupaten Semarang). Jurnal Ilmu Ekonomi dan Pembangunan, 18 (2).

B. Daraba, H.D., 2017. Pengaruh Program Dana Desa terhadap Tingkat Partisipasi Masyarakat di Kecamatan Galesong Utara Kabupaten Takalar. Sosiohumaniora, 19 (1).

C. Fitri, 2015. Kinerja pemerintah desa dalam pengelolaan alokasi Dana desa pada Desa Vatunonju Kecamatan Biromaru Kabupaten Sigi. E-Jurnal Katalogis, 3 (11).

D. Ghozali, I., 2009. Aplikasi Analisis Multivariate dengan Program IBM SPSS 19.
Badan Penerbitan Universitas Diponegoro: Semarang.

E. Kementerian Keuangan Republik Indonesia, 2017. Buku Pintar Dana Desa. Indonesia.

F. Kuncoro, M., 2010. Ekonomi Pembangunan: Teori, Masalah, dan Kebijakan. UPP AMP YKPN.

G. Kurniawan, D., 2018. 21 Desa di Bantul Belum Serahkan Laporan Pemakaian Dana Desa. Dalam http://jogjapolitan.harianjogja.com/read/2018/ 09/27/511/942219/21-desa-di-bantul-belumserahkan-laporan-pemakaian-Dana-desa-. Diakses pada 27 Oktober 2018.

H. Lokollo, E. M., 2004. Linking Farmers with Markets: Ways to reduce poverty through supply chain management. CGPRT Flash, 2 (9).

I. Mahfudz. 2009. Analisis Dampak Alokasi Dana Desa (ADD) terhadap Pemberdayaan Masyarakat dan Kelembagaan Desa. Jurnal Organisasi dan Manajemen, 5 (1).

J. Nafidah, L. Nasehatun, dan Nur Anisa, 2017. Akuntabilitas Pengelolaan Keuangan Desa di Kabupaten Jombang. Jurnal Ilmu Akuntansi, $10(2)$.

K. Oleh, H. F., 2014. Pelaksanaan Kebijakan Alokasi Dana Desa (ADD) dalam Memberdayakan Masyarakat Desa di Desa Cerme, Kecamatan Grogol, Kabupaten Kediri. Jurnal Kebijakan dan Manajemen Publik, 2 (1).

L. Pakpahan, A., 2000. Increasing the scale of small-farm operations in Indonesia. Indonesian Center for Agro Socioeconomic Research, Bogor.

M. Peraturan Menteri Desa, Pembangunan Daerah Tertinggal, dan Transmigrasi Nomor 3 tahun 2015 tentang Pendampingan Desa.

N. Pincus, J., 1996. Class Power and Agrarian Change. Land and labor in rural West Java. MacMillan Press Ltd., Great Britain, pp. 248.

O. Poerwadarminta, W. J. S., 2000. Kamus Besar Bahasa Indonesia. Balai Pustaka.

P. Rozelle, S., dan Swinnen, J. F. M., 2000. Transition and Agriculture. Dept. of Agricultural \& Resource Economics Univ. of California, Davis Working Paper No. 00-021.

Q. Saputra, I. W., 2016. Efektivitas Pengelolaan Alokasi Dana Desa pada Desa Lambean Kecamatan Kintamani, Kabupaten Bangli Tahun 2009-2014. Jurnal Jurusan Pendidikan Ekonomi, 6 (1).

R. Sari, I. M., dan Abdullah, M. F., 2017. Analisis Ekonomi Kebijakan Dana Desa terhadap Kemiskinan Desa di Kabupaten Tulungagung. Jurnal Ekonomi Pembangunan, 15 (1).

S. Sidik, H., 2018a. Legislator: alokasi Dana desa Bantul 2018 naik. Dalam 
https://jogja.antaranews.com/berita/352203/le gislator-alokasi-Dana-desa-bantul-2018-naik. Diakses pada 26 Oktober 2018.

T. Sidik, H., 2018b. Dana Desa di Bantul diprioritaskan untuk pemberdayaan masyarakat. Dalam https://jogja.antaranews.com/berita/360549/D ana-desa-di-bantul-diprioritaskan-untukpemberdayaan-masyarakat. Diakses 26 Oktober 2018.

U. Soetrisno, L., 1988. Negara dan peranannya dalam menciptakan pembangunan desa yang mandiri. Prisma No. 1 Tahun XVII, Januari 1988.

V. Sulistiyani, A. T., 2004. Kemitraan dan Model-Model Pemberdayaan. Gaya Media: Yogyakarta.

W. Tangkumahat, F. V., Panelewen, V. V. J., dan Mirah, A. D. P., 2017. Dampak Program Dana Desa Terahdap Peningkatan Pembangunan dan Ekonomi di Kecamatan Pineleng Kabupaten Minahasa. Agri-Sosio Ekonomi, 13 (2A), pp. 335-342.

X. Tjondronegoro, S. M. P., 1978. Modernisasi pedesaan: Pilihan strategi dasar menuju fase lepas landas. Prisma, 3, pp. 15-25.

Y. Undang-Undang Nomor 11 Tahun 2009 Tentang Kesejahteraan Sosial.

Z. Undang-Undang Nomor 6 Tahun 2014 Tentang Desa.

AA. Wardhana, W., 2018. Sosok Sugiono: Selalu Berusaha agar Dana Desa Bermanfaat. Dalam http://jogjapolitan.harianjogja.com/read/2018/ 09/20/511/940689/sosok-sugiyono-selaluberusaha-agar-Dana-desa-bisa-bermanfaat. Diakses pada 26 Oktober 2018. 